\title{
PENGARUH KETEPATAN WAKTU PELAPORAN, DEFAULT RISK, DAN POLITICAL CONNECTION TERHADAP KUALITAS LABA
}

\author{
Fera Anastasia Lungkang 1 \\ Muhamad Muslih ${ }^{2}$ \\ Universitas Telkom, Jawa Barat, Indonesia ${ }^{1,2}$ \\ Email: feraanastasia.lungkang@gmail.com ${ }^{1}$
}

\begin{abstract}
The earnings quality is an image of earning that do not have any uninterruptions. The earnings quality information is information that can influence investor's decision. Strong market reaction which is investor's response will be reflected in high earnings response coefficient (ERC) that shows the quality of the company's profit. This research aims to determine the effect of timeliness, default risk, and political connection on earnings quality, both simultaneously and partially. The method that used in this research was purposive sampling and obtain of 115 samples from 23 companies with period of 2014-2018. The regression model of this research used panel data regression. The results shown timeliness, default risk, and political conncetion are simultaneously influential on earnings quality. Partially, political connection negatively affects on earnings quality.

Keywords: $\quad$ Earnings quality; Earnings Response Coefficient; Timeliness; Default Risk; Political Connection.

ABSTRAK

Kualitas laba merupakan gambaran laba yang tidak memiliki gangguan. Informasi laba yang berkualitas merupakan informasi yang dapat mempengaruhi keputusan investor. Kuatnya reaksi pasar yang merupakan respon investor akan tercermin pada tingginya nilai dari earnings response coefficient (ERC) yang menggambarkan kualitas laba suatu perusahaan. Tujuan dari penelitian ini yaitu untuk menguji berpengaruhnya ketepatan waktu pelaporan, default risk, dan political connection terhadap kualitas laba yang dilakukan baik secara simultan dan parsial. Metode penelitian yang digunakan adalah purposive sampling dengan perolehan data berjumlah 115 sampel dari 23 perusahaan dengan periode penelitian tahun 2014-2018. Model regresi yang digunakan dalam penelitian adalah regresi data panel. Penelitian ini memperoleh hasil bahwa ketepatan waktu pelaporan, default risk, dan political conncetion berpengaruh secara simultan terhadap kualitas laba. Political connection secara parsial berpengaruh negatif terhadap kualitas laba.
\end{abstract}

Kata kunci: Kualitas laba; Earnings Response Coefficient; Ketepatan Waktu Pelaporan; Default Risk; Political Connection. 


\section{PENDAHULUAN}

Di era yang semakin maju ini berbagai informasi dengan mudah didapatkan. Sebagai salah satu contoh adalah kemudahan dalam memperoleh informasi perusahaan yang merupakan kebutuhan oleh pengguna perusahaan. Dalam hal ini investor membutuhan informasi seperti laba yang berkualitas sebagai bahan dalam pengambilan keputusan. Laba yang tergolong sebagai laba yang berkualitas adalah laba yang hanya sedikit ataupun tidak terdapat gangguan atau hambatan persepsi serta dapat menggambarkan kinerja keuangan dalam perusahaan yang sesungguhnya (Iglesias \& Andriana, 2017). Pada umumnya jika sajian laba yang diberikan tidak mencerminkan kinerja perusahaan maka dapat berakibat terhadap tidak tepatnya persepsi atau respon dari pengguna laporan keuangan.

Kualitas terhadap laba perusahaan dapat dilihat pada kuatnya reaksi atas pasar sebagai respon dari investor mengenai informasi yang diberikan oleh perusahaan. Respon tersebut terlihat dari tinggi nilai earnings response coefficient yang memperlihatkan adanya kualitas laba. Earnings Response Coefficient (ERC) merupakan estimasi ukuran tingkatan pengembalian abnormal sekuritas ketika memberikan respon atas komponen laba akuntansi yang tidak terduga yang dilaporkan oleh perusahaan penerbit sekuritas (Scott, 2015). Investor kemudian akan melihat kemampuan perusahaan dalam mempertahankan laba perusahaan masa depan, sehingga dari perusahaan akan memperoleh reaksi yang baik (good news) dari investor. Respon akan terjadi apabila investor memiliki persepsi informasi mengenai laporan keuangan mempunyai nilai kredibilitas yang tinggi yang kemudian dapat terlihat pada tingginya nilai ERC. Maka dari itu semakin 
besar nilai ERC yang menggambarkan reaksi yang baik dari investor, menunjukkan semakin tingginya kualitas laba dalam perusahaan.

Sektor industri dasar dan kimia merupakan salah satu sektor dari perusahaan manufaktur yang ikut menunjang pertumbuhan perekonomian negara. Namun pada salah satu perusahaan yaitu PT. Japfa Comfeed Indonesia Tbk mengalami reaksi yang tidak baik (bad news) saat mengalami kenaikan dalam laba. Terhitung sejak awal tahun hingga pada 2019, PT Japfa Comfeed Indonesia Tbk mengalami penurunan nilai saham sehingga mencapai angka 30,47\% pada level $\mathrm{Rp}$. 1.495/saham. Bursa Efek Indonesia mencatat bahwa nilai tertinggi dari Japfa sekilas mencapai Rp. 3.050/saham. Namun hal tersebut tidak bertahan dalam jangka waktu yang lama karena pencapaian turun drastis ke level paling bawah menjadi Rp. 1.300/saham, yang diakibatkan oleh rendahnya rata-rata harga daging ayam nasional. Hal tersebut menambah beban perusahaan karena pemegang saham yaitu KKR dan Co Inc yang menjual saham dari Japfa dengan nilai Rp. 853,1 miliar. Terhitung sejak awal tahun hingga bulan Juni 2019, saham Japfa amblas 30,47\%. Di sisi fundamental, pada kuartal I-2019 Japfa mengalami kenaikan penjualan dengan persentase sebesar 11,8\% yang mencapai angka Rp. 8,56 triliun (Saleh, 2019). Kenaikan penjualan pada kuartal I-2019 kemudian mengalami peningkatan pada kuartal II-2019 dan seterusnya, namun mengalami penuruan terhadap harga saham.

Publikasi infomasi dapat memberikan tanda atau sinyal terhadap investor dalam pengambilan keputusan untuk melakukan investasi (Jogiyanto, 2012). Sinyal yang diberikan dapat berbentuk laporan wajib dan pengumuman yang berkolerasi 
dengan keputusan yang ditetapkan perusahaan yang bersangkutan. Dalam teori signaling secara garis besar berkaitan erat dengan publikasi atau ketersediaan informasi. Signaling theory adalah pemberian petunjuk terhadap investor yang berkaitan dengan pandangan manajamen pada prospek perusahaan di masa depan yang merupakan perilaku dalam manajemen perusahaan (Brigham \& Houston, 2014). Hal ini menjadikan teori signaling lebih menekankan terhadap informasi penting yang perusahaan keluarkan yang kemudian dapat digunakan untuk keputusan investasi dari luar perusahaan.

Kualitas laba diartikan sebagai indikator dalam mengukur kualitas informasi keuangan dari perusahaan. Kualitas laba merupakan kemampuan laba dalam menjelaskan informasi yang terkandung pada suatu perusahaan untuk dapat berguna dalam pengambilan keputusan (Dechow et al., 2010). Terdapat dua perspektif dari kualitas laba, yaitu perspektif laba dan return. Dari sudut pandang perspektif laba, laba yang berkelanjutan dapat mencerminkan tingginya kualitas laba. Sedangkan perspektif return menyatakan terdapat hubungan dengan kinerja pasar modal dalam penentuan kualitas laba (Utami dkk., 2017).

Earnings Response Coefficient (ERC) adalah suatu pengukuran pengembalian abnormal pada saham dalam menanggapi laba tak terduga sebagai komponen yang diumumkan perusahaan penerbit (Scott, 2015). Selain itu ERC merupakan reaksi yang ditimbulkan dari adanya pengumuman laba dari perusahaan (Rullyan \& Agustin, 2015). Pada umumnya, pengukuran kualitas dari suatu laba dapat memakai earning response coefficient sebagai pengukuran terhadap banyaknya informasi yang terkandung dalam laba. Jika nilai yang ditunjukkan oleh 
ERC merupakan nilai yang tinggi maka cerminan laba yang dimiliki perusahaan akan lebih konsisten di masa depan. Maka hal ini dapat berarti laba yang dihasilkan merupakan laba yang berkualitas. Selanjutnya pihak investor akan memberikan reaksi atau respon yang baik (good news) pada perusahaan yang dinilai mampu mempertahankan laba perusahaan dimasa depan. Reaksi investor terhadap informasi tersebut digunakan sebagai dasar dalam mengambil keputusan dalam berinvestasi dan memahami performa dalam perusahaan.

Ketepatan waktu pelaporan dapat dinyatakan sebagai komponen penting dalam mempertahankan relevansi dari informasi yang diperlukan pengguna laporan keuangan perusahaan. Keterlambatan dalam penyajian laporan keuangan perusahaan dan tidak tersedianya keterangan lain terkini dari perusahaan mengakibatkan berkurangnya manfaat informasi tersebut. Sehingga ketidakpastian investor dalam membuat keputusan dapat meningkat. Ketepatan waktu adalah tersedianya informasi yang berkualitas pada saat dibutuhkan atau baiknya kualitas informasi yang dilihat dari segi waktu (Suhartono, 2015). Peraturan Otoritas Jasa Keuangan No. 29/POJK.04/2016 (OJK, 2016) mengenai laporan tahunan emiten atau perusahaan publik menyatakan bahwa penyampaian laporan tahunan perusahaan diwajibkan bagi perusahaan yang kemudian disampaikan terhadap Otoritas Jasa Keuangan maksimal selama 120 hari. Bagi setiap perusahaan yang melebihi ketentuan tersebut, maka dinyatakan terlambat dalam menyampaikan laporan tahunannya dan akan dikenakan sanksi administratif berdasarkan beratnya pelanggaran. Ketentuan sanksi yang dibuat oleh Otoritas Jasa Keuangan (OJK) yaitu dengan denda dengan nominal Rp. 1.000.000/hari. Keterlambatan tersebut 
berakibat terhadap berubahnya kepercayaan investor sehingga reaksi yang mengindikasikan adanya kabar buruk (bad news) dapat terlihat pada pasar modal.

Default risk adalah penggunaan utang dan aset yang memiliki biaya tetap dalam memberikan peningkatan terhadap laba potensial investor oleh perusahaan (Delvira \& Nelvirita, 2013). Tingginya nilai utang pada suatu perusahaan akan menaikan tingginya risiko yang investor dapatkan. Di satu sisi perusahaan yang memiliki peluang risiko tinggi dapat memberi harapan adanya penerimaan return dengan nilai tinggi. Namun di sisi yang lain risiko yang bernilai tinggi dapat memberikan ketidakpastian yang tinggi (Diantimala, 2008). Maka, informasi mengenai laba merupakan komponen yang paling direspon investor ketika membuat suatu tindakan investasi.

Default risk yang diproksikan dengan ukuran tingkat leverage yang merupakan pengukuran besarnya utang membiayai perusahaan (Fahmi, 2012). Tingginya nilai leverage akan berdampak terhadap tingginya risiko yang akan ditanggung investor. Perusahaan yang memiliki nilai utang yang tinggi, dapat memberikan peningkatan terhadap laba yang dapat memperkuat posisi dan keamanan dari bondholders dibandingkan pemegang saham. Dampaknya akan berpengaruh pada situasi pengambilan keputusan oleh investor yang semakin berhati-hati dalam membuat keputusan terkait dengan perusahaan yang memiliki risiko yang tinggi.

Political connection (koneksi politik) adalah hubungan yang terjadi apabila salah satu petinggi perusahaan atau pemegang saham yang merupakan anggota atau 
mantan anggota parlemen, menteri, dan/atau yang memiliki hubungan dekat dengan politisi dari negara lain (Faccio, 2006). Koneksi politik menjadikan suatu perusahaan memperoleh perlakuan yang spesial dibandingkan perusahaan yang tidak memiliki koneksi politik seperti dimudahkan dalam proses peminjaman modal dan juga dalam menghindari risiko pemeriksaan pajak rendah.

Political connection cenderung menjadikan perusahaan sebagai perusahaan yang risk taker. Hal ini diakibatkan adanya pengaruh negatif dari political connection yang menunjukkan jika ada petinggi perusahaan yang terkoneksi politik mengakibatkan fungsi pengawasan tidak dapat berjalan secara maksimal dengan baik, sehingga mengakibatkan penurunan kinerja dari perusahaan. Artinya perusahaan dengan political connection terindikasi rentan mengalami kesulitan keuangan sehingga memungkinkan untuk mengalami penurunan terhadap kualitas laba (Narayanaswamy, 2013).

Ketepatan waktu adalah kualitas dari ketersediaanya informasi saat diperlukan atau kualitas informasi yang dapat dilihat dari segi waktunya (Suhartono, 2015). Semakin cepat informasi diterima makan semakin berkualitas nilai dari informasi tersebut. Keterlambatan akan berdampak terhadap keputusan investor yang menjadi ragu karena meningkatnya ketidakpastian. Maka dari itu, makin tepat waktu sebuah perusahaan menyampaikan laporan keuangan, maka semakin meningkatkan kualitas laba yang diproksikan dengan ERC (Dewi \& Idawati, 2017).

$\mathrm{H}_{1}$ : Ketepatan waktu pelaporan berpengaruh positif terhadap kualitas laba 
Risiko penggunaan utang yang tinggi menyebabkan investor menjadi hatihati dalam membuat keputusan dikarenakan tingginya risiko perusahaan (Indriaty \& Tania, 2018). Sikap ini akan menjadi penyebab investor lebih lambat atau juga bisa tidak memberikan reaksi atas informasi laba. Sehingga tingkat risiko yang dimiliki perusahaan dapat mempengaruhi hubungan laba dan return perusahaan. Default risk mencerminkan tingginya tingkat hutang perusahaan, sehingga dapat terlihat bahwa kualitas perusahaan di masa depan berada pada situasi yang kurang baik (Rahayu, 2015).

$\mathrm{H}_{2}$ : Default Risk berpengaruh negatif terhadap kualitas laba

Perusahaan berhubungan dalam politik cenderung beresiko yang berarti perusahaan dengan political connection terindikasi rentan mengalami kesulitan keuangan sehingga memungkinkan untuk mengalami penurunan terhadap kualitas laba (Narayanaswamy, 2013). Pengaruh negatif dari political connection yang menunjukkan bahwa jika ada petinggi perusahaan yang terkoneksi politik mengakibatkan fungsi pengawasan tidak dapat berjalan secara maksimal dengan baik, sehingga mengakibatkan penurunan kinerja dari perusahaan (Hashmi et al., 2018).

$\mathrm{H}_{3}$ : $\quad$ Political Connection berpengaruh negatif terhadap kualitas laba

Berdasarkan teori yang telah ditemukan sebelumnya, maka unttuk hipotesis selanjutnya yaitu hipotesis yang menjelaskan pengaruh secara simultan dari variabel ketepatan waktu pelaporan, default risk, dan political connection terhadap kualitas laba sehingga memperoleh hipotesis sebagai berikut: 
$\mathrm{H}_{4}$ : Ketepatan waktu pelaporan, default risk, dan political connection berpengaruh secara simultan terhadap kualitas laba pada perusahaan di sektor industri dasar dan kimia yang terdaftar di BEI tahun 2014-2018.

\section{METODE PENELITIAN}

Penelitian ini dilakukan pada perusahaan sektor industri dasar dan kimia yang terdaftar di Bursa Efek Indonesia (BEI). Kualitas laba adalah objek penelitian pada perusahaan industri dasar dan kimia yang terdaftar dan menyajikan laporan keuangan tahunan secara konsisten dan memiliki data terkait ketepatan waktu pelaporan, default risk, dan political connection dengan periode penelitian selama tahun 2014-2018 di BEI dan situs resmi perusahaan. Populasi pada penelitian ini adalah perusahaan industri dasar dan kimia yang terdaftar di Bursa Efek Indonesia periode 2014-2018 yaitu sebanyak 59 perusahaan. Pengambilan sampel yang digunakan yaitu purposive sampling sehingga sampel yang diperoleh berjumlah 23 perusahaan selama 5 tahun sehingga diperoleh sebanyak 115 pengamatan. Adapun dalam pengumpulan data terdapat beberapa data yang menghasilkan pengujian statistik tidak dapat digunakan sebagai dasar pengambilan keputusan. Maka dari itu dilakukan outlier dan menghasilkan sebanyak 50 data dari 10 perusahaan sektor industri dasar dan kimia dengan periode 2014-2018.

Kualitas laba diproksikan dengan ERC yang mana menggambarkan respon atas laba yang diumumkan perusahaan. Reaksi investor terhadap informasi digunakan sebagai bahan pemikiran dalam membuat keputusan investasi serta 
untuk mengetahui performa perusahaan. ERC diperoleh dengan melalui tahap perhitungan (Hartono, 2017) sebagai berikut:

Mencari return saham harian dan return pasar harian. Perhitung return saham harian sebagai berikut:

$$
\text { Rit }=\frac{\text { Pit }- \text { Pit }-1}{\text { Pit }-1}
$$

Notasi:

Rit = return saham perusahaan i pada hari $\mathrm{t}$

Pit = harga penutupan saham pada hari $\mathrm{t}$

Pit-1 = harga penutupan saham i pada hari $\mathrm{t}-1$

Return pasar harian dapat dihitung dengan menggunakan persamaan berikut:

$$
\mathrm{RMt}=\frac{I H S G \mathrm{t}-I H S G \mathrm{t}-1}{I H S G \mathrm{t}-1}
$$

Notasi:

$\mathrm{RMt}=$ return pasar harian

IHSG $\mathrm{t}=$ indeks harga saham gabungan pada hari $\mathrm{t}$

IHSG $\mathrm{t}-1$ = indeks harga saham harian pada hari $\mathrm{t}-1$

Setelah return saham dan return pasar harian selesai dihitung, maka selanjutnya melakukan perhitungan abnormal return dengan menggunakan model market adjusted model. Sehingga diperoleh persamaan sebagai berikut:

$$
A R i, t=R i, t-R m, t
$$

Notasi:

ARi,t = abnormal return pada perusahaan i periode $\mathrm{t}$

$\mathrm{Ri}, \mathrm{t}=$ return perusahaan i pada periode $\mathrm{t}$

$\mathrm{Rm}, \mathrm{t}=$ return pasar pada periode ke-t

Kemudian menghitung Cummulative Abnormal Return (CAR) dengan 
menggunakan rumus:

$$
C A R i t=\sum A R i, t
$$

Notasi:

CARi = abnormal return kumulatif perusahaan i selama periode pengamatan.

$\mathrm{ARi}, \mathrm{t}=$ abnormal return pada perusahaan i pada hari $\mathrm{t}$.

Langkah selanjutnya yaitu perhitungan selisih laba sesungguhnya dengan laba ekspektasi. Unexpected earnings diukur dengan menggunakan dengan model random walk, dengan persamaan sebagai berikut:

$$
\mathrm{UEi}, \mathrm{t}=\frac{(E \mathrm{it}-E \mathrm{it}-1)}{E \mathrm{it}-1}
$$

Notasi:

$\mathrm{UEi}, \mathrm{t} \quad=$ unexpected earnings perusahaan $\mathrm{i}$ pada periode $\mathrm{t}$

Eit $\quad=$ earnings after tax perusahaan $\mathrm{i}$ pada periode $\mathrm{t}$

Eit-1 = earnings after tax perusahaan i pada periode $\mathrm{t}-1$

Menghitung earnings response coefficient yang diperoleh dari regresi antara CAR dengan UE. Perhitungan ERC adalah sebagai berikut:

$$
C A R=\alpha 0+\alpha 1 \mathrm{UEit}+\text { Eit. }
$$

Notasi:

$$
\begin{array}{ll}
\mathrm{CAR} & =\text { abnormal return kumulatif perusahaan i selama periode amatan } \\
\mathrm{UEi}, \mathrm{t} & =\text { unexpected earnings } \\
\alpha 0 & =\text { konstanta } \\
\text { eit } & =\text { komponen error dalam model atas perusahaan i pada periode } \mathrm{t}
\end{array}
$$

Ketepatan waktu pelaporan merupakan komponen penting dalam menjaga relevansinya informasi yang dibutuhkan bagi para pengguna laporan keuangan. Keterlambatan dalam penyajian laporan keuangan dan tidak tersedianya informasi 
dapat menyebabkan kurang bermanfaatnya informasi yang dihasilkan. Dalam Peraturan Otoritas Jasa Keuangan No. 29/POJK.04/2016 mengenai laporan tahunan emiten atau perusahaan publik yang menyatakan bahwa perusahaan wajib menyampaikan laporan tahunan kepada Otoritas Jasa Keuangan paling lambat selama 120 hari setelah tahun buku berakhir. Ketepatan waktu pelaporan diukur berdasarkan kuantitatif dengan jumlah hari sejak tanggal tutup tahun buku sampai ke tanggal penyerahan.

Default risk diproksikan dengan menggunakan ukuran tingkat leverage yang merupakan indikator untuk mengukur seberapa besar utang membiayai perusahaan (Fahmi, 2012). Adapun perhitungan rasio leverage yang digunakan berdasarkan dari nilai total utang dan total aset sebagai berikut:

$$
\text { Lit }=\frac{\text { Tuit }}{\text { Tait }}
$$

Notasi:

Lit $=$ Leverage perusahaan i pada tahun $\mathrm{t}$

TUit = Total utang perusahaan $\mathrm{i}$ pada tahun $\mathrm{t}$

TAit $=$ Total aset perusahaan i pada tahun $\mathrm{t}$

Political connection diukur menggunakan variabel dummy dengan menggunakan kriteria diberikan nilai 0 apabilai tidak memiliki political connection dan nilai 1 apabila memiliki kriteria (Ding et al., 2007) sebagai berikut ini: 1). Presiden komisaris dan/atau komisaris independen rangkap jabatan sebagai politisi yang berafiliasi dengan partai politik. 2). Presiden komisaris dan/atau komisaris independen rangkap jabatan sebagai pejabat pemerintah. 3). Presiden 
komisaris dan/atau komisaris independen rangkap jabatan sebagai pejabat militer. 4). Presiden komisaris dan/atau komisaris independen merupakan mantan pejabat pemerintah atau mantan pejabat militer.

Adapun teknik analisis yang digunakan yaitu analisis regresi data panel, dengan persamaaan yang dirumuskan sebagai berikut:

$\mathrm{Y}=\alpha+\beta 1 \mathrm{X} 1+\beta 2 \mathrm{X} 2+\beta 3 \mathrm{X} 3+\varepsilon$

Notasi:

$\mathrm{Y} \quad=$ Kualitas Laba

$\alpha \quad=$ Konstanta

$\beta=$ Koefisien regresi

$\mathrm{X} 1=$ Ketepatan waktu pelaporan

$\mathrm{X} 2=$ Default Risk

$\mathrm{X} 3=$ Political Connection

$\varepsilon \quad=$ error

\section{HASIL DAN PEMBAHASAN}

Hasil pengujian statistik deskriptif berskala rasio pada masing-masing variabel berdasarkan Tabel 1 (Lampiran 1) pada variabel kualitas laba yang diproksikan dengan ERC pada perusahaan sektor industri dasar dan kimia yang terdaftar di BEI periode 2014-2018 memiliki nilai minimum dengan angka sebesar -2.91 pada tahun 2016 yang dimiliki PT Kertas Basuki Rachmat Indonesia Tbk (KBRI). Selanjutnya nilai maksimum dengan angka sebesar 2.86 pada tahun 2016 dimiliki PT Champion Pacific Indonesia Tbk (IGAR). Nilai rata-rata kualitas laba berada pada nilai sebesar 0.05 serta nilai standar deviasi sebesar 0.87 . Kesimpulan yang diperoleh dari hasil analisis deskriptif ini adalah perusahaan pada sektor industri dasar dan kimia memiliki nilai mean yang positif pada kualitas laba, 
sehingga hal tersebut berarti informasi laba dari perusahaan sektor industri dasar dan kimia mendapatkan respon yang bagus (good news) dari investor. Nilai standar deviasi yang lebih besar dibandingkan nilai mean menunjukkan adanya varian yang tinggi, sehingga kelompok data sangat bervasiasi atau relatif heterogen, menyebar dan jauh dari nilai rata-rata.

Pada variabel ketepatan waktu pelaporan yang diproksikan dengan menggunakan jumlah hari, terhitung sejak tanggal tutup tahun buku (31 Desember) sampai ke tanggal penyerahan Bapepam (saat ini OJK) pada perusahaan sektor industri dasar dan kimia yang terdaftar di BEI periode 2014-2018 memiliki nilai minimum dengan angka sebesar 64 pada tahun 2014 yang dimiliki oleh PT Champion Pacific Indonesia Tbk (IGAR). Selanjutnya nilai maksimum dengan angka sebesar 133 pada tahun 2016 dimiliki oleh PT Kertas Basuki Rachmat Indonesia Tbk (KBRI). Nilai rata-rata ketepatan waktu pelaporan berada pada nilai sebesar 99.16 dan standar deviasi sebesar 16.13. Kesimpulan yang diperoleh dari hasil analisis deskriptif adalah perusahaan pada sektor industri dasar dan kimia memiliki nilai mean yang positif pada ketepatan waktu pelaporan, artinya adanya pengaruh dari ketersediaan informasi dalam pengambilan keputusan yang disebabkan oleh ketepatan dalam penyampaian pelaporan sehingga menimbulkan sinyal yang baik (good news). Nilai standar deviasi lebih rendah dibandingkan nilai mean sehingga menunjukkan varian yang rendah, yang berarti kelompok data tidak bervariasi atau relatif homogen, berkelompok dan mendekati dari nilai rata-rata.

Pada variabel default risk yang dihitung dengan rasio leverage pada perusahaan sektor industri dasar dan kimia yang terdaftar di BEI periode 2014-2018 
memiliki nilai minimum dengan angka sebesar 0.14 pada tahun 2017 yang dimiliki PT Champion Pacific Indonesia Tbk (IGAR). Selanjutnya nilai maksimum dengan angka sebesar 24.5976 pada tahun 2017 yang dimiliki PT Central Proteina Prima Tbk (CPRO). Default risk memiliki nilai rata-rata sebesar 0.50 dan standar deviasi sebesar 0.31. Kesimpulan yang diperoleh dari hasil analisis statistik deskriptif ini adalah perusahaan pada sektor industri dasar dan kimia memilik nilai mean yang positif pada default risk dan kurang dari satu, sehingga menunjukkan risiko yang akan ditanggung oleh investor mengalami peningkatan sebesar 0.5 kali. Nilai standar deviasi lebih rendah dibandingkan nilai mean sehingga menunjukkan varian yang rendah, yang berarti kelompok data tidak bervariasi atau relatif homogen, berkelompok dan mendekati dari nilai rata-rata.

Hasil pengujian statistik deskriptif berskala nominal pada variabel political conncetion yang dapat dilihat pada Tabel 2 (Lampiran 2) yang mana menunjukkan bahwa jumlah dari observasi pada perusahaan sektor industri dasar dan kimia yang terdaftar di Bursa Efek Indonesia periode 2014-2018 yang memiliki hubungan politik adalah sebanyak 15 observasi atau sebesar 30\%. Di sisi lain, terdapat sebanyak 35 observasi atau sebesar $70 \%$ tidak memiliki hubungan politik dalam perusahaan sektor industri dasar dan kimia yang terdaftar di Bursa Efek Indonesia periode 2014-2018. Hal ini menunjukkan bahwa mayoritas perusahaan industri dasar dan kimia tidak memiliki political connection.

Uji asumsi klasik bertujuan untuk mengetahui apakah dalam pengujian data yang digunakan terjadi atau tidak gejala multikolonieritas dan gejala heterokedastisitas. Uji multikolinieritas adalah uji yang bertujuan untuk 
menemukan korelasi yang mendekati atau sempurna antar variabel independen pada mode regresi. Hasil analisis pada Tabel 3 (Lampiran 3) menyatakan ketepatan waktu pelaporan (TIMELINESS), default risk (LIT), dan political connection (CONNECT) berturut-turut adalah $-0.056541,-0.119929$, dan 0.132003 . Kesimpulan yang diperoleh adalah tidak terjadi multikolonieritas karena nilai korelasi $<0.8$.

Uji Heterokedastisitas merupakan uji yang terjadi jika terdapat varians yang berbeda untuk variabel independen yang berbeda. Hasil yang diperoleh dari Tabel 4 (Lampiran 4) adalah nilai probabilitas dari setiap variabel independen $>0.05$, maka dapat disimpulkan bahwa dalam penelitian ini tidak terdapat gejala heterokedastistias.

Hasil uji koefisien determinasi dan simultan bertujuan untuk menjelaskan mengenai pengaruh simultan dari variabel ketepatan waktu pelaporan, default risk, dan political connection terhadap kualitas laba. Pada Tabel 5 (Lampiran 5) menunjukkan nilai adjusted r-squared sebesar 0.403184 dengan nilai probabilitas (f-statistic) sebesar $0.000933<\alpha=0.05$, yang berarti variabel ketepatan waktu pelaporan, default risk, dan political connection mampu menggambarkan variasi dari kualitas laba sebesar $40.3 \%$ dan sisanya $59.7 \%$ digambarkan oleh faktor lain. Sehingga ketepatan waktu pelaporan, default risk, dan political connection berpengaruh secara simultan terhadap kualitas laba.

Tujuan dari pengujian secara parsial adalah untuk menjelaskan pengaruh parsial dari masing-masing variabel independen yang terdiri dari ketepatan waktu 
pelaporan, default risk, dan political connection terhadap kualitas laba. Pada Tabel 6 (Lampiran VI) menunjukkan nilai koefisien regresi data panel yang membentuk persamaan sebagai berikut:

$\mathrm{Y}=5,181.780+0.003949$ TIMELINESS $-1.726527 \mathrm{LIT}-17,270.33$ CONNECT $+\varepsilon \ldots .(9)$

Persamaan dari regresi dapat diartikan sebagai berikut: Nilai konstanta sebesar 5,181.780 dengan tingkat probabilitas 0.0001 kurang dari $\alpha=0.05$, berarti jika variabel independen yaitu ketepatan waktu pelaporan, default risk, dan political connection bernilai 0 atau konstan, maka kualitas laba sebesar 5,181.780

Variabel ketepatan waktu pelaporan $\left(\mathrm{X}_{1}\right)$ mendapatkan nilai probabilitas sebesar 0.5593 yang berarti memiliki nilai lebih besar dari taraf signifikansi 0.05. Hal ini berarti ketepatan waktu pelaporan tidak berpengaruh terhadap kualitas laba secara parsial. Selain itu ketepatan waktu pelaporan memperoleh nilai koefisien sebesar 0.003949 yang menunjukkan bahwa variabel ini memiliki arah hubungan yang positif. Ketepatan waktu merupakan kualitas dari tersediaanya informasi pada saat diperlukan. Namun hal ini juga masih tergantung pada reaksi dari investor yang melihat faktor lain dari laporan keuangan selain ketepatan waktu pelaporannya. Hal ini dikarenakan ketepatan dalam penyampaian laporan keuangan hanya mengindikasikan sinyal yang mana jika terjadi keterlambatan maka dianggap adanya indikasi sinyal buruk (bad news) dan sebaliknya ketepatan waktu pelaporan akan mengindikasikan adanya sinyal baik (good news). Sedangkan dalam penelitian ketepatan waktu pelaporan lebih mengharapkan kepastian adanya sinyal yang baik (good news). Maka dari itu, ketepatan waktu pelaporan tidak berpengaruh secara 
signifikan terhadap kualitas laba. Hal ini sejalan dengan penelitian yang menyatakan bahwa ketepatan waktu pelaporan tidak berpengaruh terhadap kualitas laba (Fauzan \& Purwanto, 2017).

Variabel default risk $\left(\mathrm{X}_{2}\right)$ mendapatkan nilai probabilitas sebesar 0.1735 yang berarti memiliki nilai lebih besar dari taraf signifikansi 0.05 . Hal ini berarti default risk tidak berpengaruh terhadap kualitas laba secara parsial. Selain itu default risk memperoleh nilai koefisien sebesar -1.726527 yang menunjukkan bahwa variabel ini memiliki arah hubungan yang negatif. Default risk mencerminkan tingginya tingkat utang perusahaan, sehingga menunjukkan kualitas dari perusahaan yang kurang baik dimasa yang mendatang. Semakin tinggi utang yang dimiliki oleh perusahaan maka semakin tinggi juga risiko yang akan diterima oleh investor. Namun perusahaan yang memiliki risiko tinggi bisa juga menjanjikan return yang tinggi. Akan tetapi di sisi lain juga hal tersebut dapat memberikan ketidakpastian yang tinggi. Berdasarkan hasil pengolahan data di atas, default risk belum dapat menjadi dasar tolak ukur oleh investor untuk menentukan kualitas laba sebuah perusahaan dalam membuat keputusan. Hal ini dikarenakan adanya kemungkin investor yang memilih perusahaan yang memiliki tingkat utang yang tinggi sehingga memiliki risiko yang tinggi juga untuk memperoleh return perusahaan yang tinggi. Sedangkan dalam penelitian ini default risk menekankan bahwa tingkat utang yang tinggi akan menaikan tingkat risiko sehingga berdampak pada besarnya risiko yang akan diterima oleh investor. Maka dari itu, default risk tidak berpengaruh secara signifikan terhadap kualitas laba. Hal ini sejalan dengan penelitian yang menyatakan bahwa default risk tidak berpengaruh terhadap kualitas 
laba yang diproksikan dengan earnings response coefficient (ERC) (Sulung \& Muslih, 2019).

Variabel political connection $\left(\mathrm{X}_{3}\right)$ mendapatkan nilai probabilitas sebesar 0.0001 yang berarti memiliki nilai kurang dari taraf signifikansi 0.05 . Hal ini berarti political connection berpengaruh terhadap kualitas laba secara parsial. Selain itu political connection memperoleh nilai koefisien sebesar -17,270.33 yang menunjukkan bahwa variabel ini memiliki arah hubungan yang negatif. Sehingga penelitan ini sejalan dengan kerangka penelitian yang menyatakan bahwa political connection berpengaruh negatif dan signifikan terhadap kualitas laba. Hal ini menunjukkan terjalinnya suatu hubungan antara suatu pihak tertentu dengan pihak yang memiliki kepentingan dalam politik dapat mempengaruhi probabilitas kualitas laba dalam perusahaan. Perusahaan yang memiliki political connection cenderung menjadi perusahaan risk taker. Hal ini menunjukkan bahwa perusahaan dengan political connection terindikasi rentan mengalami kesulitan keuangan sehingga memungkinkan untuk mengalami penurunan terhadap kualitas laba perusahaan. Political connection memiliki pengaruh yang menunjukkan bahwa jika ada petinggi perusahaan yang terkoneksi politik mengakibatkan fungsi pengawasan tidak dapat berjalan secara maksimal dengan baik, sehingga mengakibatkan penurunan kinerja dari perusahaan. Hal ini sejalan dengan penelitian yang dilakukan oleh Narayanaswamy (2013); Hashmi et al., (2018) yang menyatakan bahwa political connection berpengaruh negatif terhadap kualitas laba yang diproksikan dengan earnings response coefficient (ERC). 


\section{SIMPULAN DAN SARAN}

Pengaruh secara parsial variabel independen terhadap kualitas laba adalah sebagai berikut: 1). Ketepatan waktu pelaporan tidak berpengaruh secara signifikan terhadap kualitas laba pada perusahaan sektor industri dasar dan kimia yang terdaftar di Bursa Efek Indonesia periode 2014-2018. 2). Default risk tidak berpengaruh secara signifikan terhadap kualitas laba pada perusahaan sektor industri dasar dan kimia yang terdaftar di Bursa Efek Indonesia periode 2014-2018. 3). Political connection berpengaruh secara signifikan dengan arah negatif terhadap kualitas laba pada perusahaan sektor industri dasar dan kimia yang terdaftar di Bursa Efek Indonesia periode 2014-2018. Sementara itu, berdasarkan hasil uji simultan variabel independen yang terdiri dari ketepatan waktu pelaporan, default risk, dan political connection secara simultan atau bersama-sama berpengaruh terhadap kualitas laba pada perusahaan sektor industri dasar dan kimia yang terdaftar di Bursa Efek Indonesia periode 2014-2018.

Disarankan untuk peneliti selanjutnya agar dapat menguji kembali variabel independen yang tidak berpengaruh terhadap variabel dependen, seperti ketepatan waktu pelaporan dan default risk, dengan menggunakan indikator lain seperti variabel dummy untuk ketepatan waktu pelaporan. Bagi perusahaan diharapkan untuk dapat memperhatikan faktor yang mempengaruhi kualitas laba dalam perusahaan, seperti political connection yang memiliki pengaruh negatif terhadap kualitas laba. Bagi investor, hasil penelitian ini dapat dijadikan sebagai faktor untuk bahan pertimbangan dalam menentukan keputusan terhadap calon perusahaan yaitu 
selain informasi keuangan, perlu juga memperhatikan faktor lain seperti perusahaan yang memiliki political connection.

\section{REFERENSI}

Brigham, E. F., \& Houston, J. F. (2014). Dasar-Dasar Manajemen Keuangan. Jakarta: Salemba Empat.

Dechow, P., Ge, W., \& Schrand, C. (2010). Understanding earnings quality: A review of the proxies, their determinants and their consequences \$. Journal of Accounting and Economics, 50(2-3), 344-401. https://doi.org/10.1016/j.jacceco.2010.09.001

Delvira, M., \& Nelvirita. (2013). Pengaruh Risiko Sistematik , Leverage Dan Persistensi Laba Terhadap Earnings Response Coefficient ( ERC ). Jurnal WRA, 1(1), 129-154.

Dewi, I. G. A. R. P., \& Idawati, P. D. P. (2017). Keuangan Dan Dampaknya Pada Earning Response Coefficient, Jurnal Ilmiah Akuntansi dan Bisnis.2(1):207-222

Diantimala, Y. (2008). Pengaruh Akuntansi Konservatif, Ukuran Perusahaan, Dan Default Risk Terhadap Koefisien Respon Laba ( ERC ). Jurnal Telaah \& Riset Akuntansi, 1(1), 102-122.

Ding, Y., Zhang, H., \& Zhang, J. (2007). Private vs State Ownership and Earnings Management : evidence from Chinese listed companies. Journal Corporate Governance an International Review, 15(2), 223-238.

Faccio, M. (2006). Differences Between Politically Connected And Non-Connected Firms: A Cross Country Analysis Mara. Financial Management Journal, 39(3), 905-927. Retrieved from http://jurnal.iseibandung.or.id/index.php/ier

Fahmi, I. (2012). Pengantar Pasar Modal. Bandung: Alfabeta.

Fauzan, M., \& Purwanto, A. (2017). Pengaruh Pengungkapan Csr, Timeliness, Profitabilitas, Pertumbuhan Perusahaan Dan Resiko Sistematik Terhadap Earning Response Coefficient (Erc). Diponegoro Journal Of Accounting, $6(1), 1-15$.

Hartono, J. (2017). Teori Portofolio dan Analisis Investasi (11th ed.). Yogyakarta: BPFE.

Hashmi, M. A., Brahmana, R. K., \& Lau, E. (2018). Political connections , family 
fi rms and earnings quality. Management Research Review, 41(4), 414-432. https://doi.org/10.1108/MRR-05-2017-0136

Iglesias, Y., \& Andriana, D. (2017). Pengaruh Pengungkapan Sukarela Pada Laporan Tahunan Terhadap Kualitas Laba Pada Perusahaan Pertambangan. Jurnal Aset (Akuntansi Riset), 187-198.

Indriaty, L., \& Tania, D. (2018). Pengaruh Csr Disclosure, Kesempatan Bertumbuh Dan Risiko Kegagalan Perusahaan. WAHANA, 21(2), 54-65.

Jogiyanto, H. (2012). Pasar Efisien Secara Informasi, Operasional, dan Keputusan (Edisi 3). Yogyakarta: BPFE.

Narayanaswamy, R. (2013). Working Paper No : 433 Political Connections and Earnings Quality: Evidence from India, (November), 1-21.

OJK. (2016). Otoritas jasa keuangan republik indonesia.

Rahayu, L. P. A. K. (2015). Pengaruh ukuran perusahaan dan risiko gagal bayar pada koefisien respon laba, 13(2), 665-684.

Rullyan, A., \& Agustin, H. (2015). Pengaruh Default Risk , Profitabilitas dan Resiko Sistematis Terhadap Earnings Response Coefficient ( Studi Empiris pada Perusahaan yang terdaftar di BEI Tahun 2011-2014 ), 961-978.

Saleh, T. (2019, June 11). Saham Japfa Dilepas Investor Asing Rp 1,69 T, Ada Apa Sih. CNBC Indonesia. Retrieved from https://www.cnbcindonesia.com/market/20190611105541-1777531/saham-japfa-dilepas-investor-asing-rp-169-t-ada-apa-sih

Scott, W. R. (2015). Financial Accounting Theory Sevent edition (7th ed.). Canada: Prentice Hall.

Suhartono, S. (2015). Pengaruh Ukuran Perusahaan, Struktur Modal, Dan Ketepatan Waktu Penyampaian Laporan Keuangan Terhadap Koefisien Respon Laba Yang Dimoderasi Konservatisme Akuntansi, 22(2), 189-217.

Sulung, E., \& Muslih, M. (2019). Pengaruh Kualitas Corporate Social Responsibility, Default Risk, Dan Profitabilitas Terhadap Earnings Response Coefficient ( Studi pada Perusahaan Pertambangan yang Terdaftar di BEI Tahun 2013-2018 ) The Effect Of Corporate Social Responsibility Quality. E-Proceeding of Management, 6(2), 3098-3105.

Utami, T., Kusuma, \& Wijaya, I. (2017). Detirminan Kualitas Laba pada Isu Pengadopsian Internasional Financial Reporting Standard: Data dari Asia. Jurnal Akuntansi Dan Investasi, 18(1):1-12 


\section{LAMPIRAN I}

Tabel 1. Hasil Uji Statistik Deskriptif Skala Rasio

\begin{tabular}{cccccc}
\hline & N & Minimum & Maximum & Mean & Std. Deviation \\
\hline Kualitas Laba & 50 & -2.91 & 2.86 & 0.05 & 0.87 \\
$\begin{array}{c}\text { Ketepatan Waktu } \\
\text { Pelaporan }\end{array}$ & 50 & 64 & 133 & 99.16 & 16.13 \\
Default Risk & 50 & 0.14 & 1.25 & 0.5 & 0.31 \\
\hline
\end{tabular}

Sumber: Data diolah, 2020

\section{LAMPIRAN II}

Tabel 2. Hasil Uji Statistik Deskriptif Skala Nominal

\begin{tabular}{cccc}
\hline & \multicolumn{2}{c}{ Political Connection } & \\
\cline { 2 - 3 } & $\begin{array}{c}\text { Memiliki political } \\
\text { connection }\end{array}$ & $\begin{array}{c}\text { Tidak memiliki political } \\
\text { connection }\end{array}$ & Jumlah \\
\hline Jumlah Data & 15 & 35 & 50 \\
\hline Persentase & $30 \%$ & $70 \%$ & $100 \%$ \\
\hline Sumber: Data diolah, 2020 & & &
\end{tabular}

\section{LAMPIRAN III}

Tabel 3. Hasil Uji Multikoloniaritas

\begin{tabular}{ccccc}
\hline & ERC & TIMELINESS & LIT & CONNECT \\
\hline ERC & 1.000000 & -0.056541 & -0.119929 & 0.132003 \\
\hline TIMELINESS & -0.056541 & 1.000000 & 0.119552 & -0.061227 \\
\hline LIT & -0.119929 & 0.119552 & 1.000000 & 0.231805 \\
\hline CONNECT & 0.132003 & -0.061227 & 0.231805 & 1.000000 \\
\hline
\end{tabular}

Sumber: Data diolah, 2020 


\section{LAMPIRAN IV}

\section{Tabel 4. Hasil Uji Heterokedastisitas}

Dependent Variable: RESABS

Method: Panel Least Squares

Date: 05/07/20 Time: 10:24

Sample: 20142018

Periods included: 5

Cross-sections included: 10

Total panel (balanced) observations: 50

\begin{tabular}{crrrr}
\hline \hline Variable & Coefficient & Std. Error & t-Statistic & Prob. \\
\hline \hline C & -0.007040 & 0.056612 & -0.124353 & 0.9016 \\
TIMELINESS & 0.000839 & 0.000560 & 1.499371 & 0.1406 \\
LIT & -0.051569 & 0.030000 & -1.718957 & 0.0923 \\
CONNECT & 0.022337 & 0.019900 & 1.122475 & 0.2675 \\
\hline
\end{tabular}

Sumber: Data diolah, 2020

\section{LAMPIRAN V}

Tabel 5. Hasil Uji Koefisien Determinasi dan Simultan

\begin{tabular}{lrll}
\hline R-squared & 0.549343 & Mean dependent var & 0.045036 \\
Adjusted R-squared & 0.403184 & S.D. dependent var & 0.867299 \\
S.E. of regression & 0.670022 & Akaike info criterion & 2.255882 \\
Sum squared resid & 16.61038 & Schwarz criterion & 2.753008 \\
Log likelihood & -43.39705 & Hannan-Quinn criter. & 2.445190 \\
F-statistic & 3.758531 & Durbin-Watson stat & 2.235690 \\
Prob(F-statistic) & 0.000933 & & \\
\hline
\end{tabular}

Sumber: Data diolah, 2020

\section{LAMPIRAN VI}

\section{Tabel 6. Hasil Uji Parsial}

Dependent Variable: ERC

Method: Panel Least Squares

Date: 05/07/20 Time: 10:10

Sample: 20142018

Periods included: 5

Cross-sections included: 10

Total panel (balanced) observations: 50

\begin{tabular}{crrrr}
\hline \hline Variable & Coefficient & Std. Error & t-Statistic & Prob. \\
\hline \hline C & 5181.780 & 1146.803 & 4.518455 & 0.0001 \\
TIMELINESS & 0.003949 & 0.006702 & 0.589187 & 0.5593 \\
LIT & -1.726527 & 1.244005 & -1.387878 & 0.1735 \\
CONNECT & -17270.33 & 3822.222 & -4.518401 & 0.0001 \\
\hline
\end{tabular}

Sumber: Data diolah, 2020 